\title{
Synthesis of micro-size magnetic polymer adsorbent and its application for the removal of $\mathrm{Cu}$ (II) ion
}

\author{
Jyi-Yeong Tseng ${ }^{a}$, Ching-Yuan Chang ${ }^{a}, *$, Yi-Hung Chen ${ }^{\mathrm{b}}$, \\ Chiung-Fen Chang ${ }^{c}$, Pen-Chi Chiang ${ }^{a}$ \\ ${ }^{a}$ Graduate Institute of Environmental Engineering, National Taiwan University, 71 Chou-Shan Road, Taipei 106, Taiwan \\ ${ }^{\mathrm{b}}$ Department of Chemical and Material Engineering, National Kaohsiung University of Applied Sciences, Kaohsiung 807, Taiwan \\ ${ }^{\mathrm{c}}$ Department of Environmental Science and Engineering, Tunghai University, Taichung 407, Taiwan
}

Received 14 April 2006; received in revised form 24 August 2006; accepted 1 September 2006

Available online 6 September 2006

\begin{abstract}
This study is aimed at the synthesis of micro-size magnetic polymer adsorbent (MPA) coupling with metal chelating ligands of iminodiacetic acid (IDA) and its application for the removal of $\mathrm{Cu}$ (II) ion. Firstly, the super-paramagnetic $\mathrm{Fe}_{3} \mathrm{O}_{4}$ called magnetite was prepared via the chemical co-precipitation method. The magnetite was then coated with polyvinyl acetate (PVAC) via the suspension polymerization with vinyl acetate (VAC), yielding magnetite-PVAC (denoted as M-PVAC). Several sequential procedures, including alcoholysis, epoxide activation, and coupling of IDA were subsequently employed to introduce functional groups on the surface of super-paramagnetite particles of M-PVAC, without demolishing the magnetite within the particles. The above sequential procedures yielded magnetite-polyvinyl alcohol (M-PVAL), magnetite-polyvinyl propenepoxide (M-PVEP), and magnetite-polyvinyl acetate-IDA (M-PVAC-IDA), respectively. Hence, the micro-size M-PVAC coupling with chelating ligands of IDA (denoted as M-PVAC-IDA) was manufactured with the desired chemical properties. The micro-size of about $1 \mu \mathrm{m}$ and specified functional groups of metal chelating ligands of M-PVAC-IDA can provide large specific area of external surface and adsorbability of metal ions of adsorbent, respectively, which are essential to the adsorption. Moreover, after the use in adsorption, the exhausted M-PVAC-IDA with super-paramagnetic property can be separated from the solution via the applied magnetic force.

As for the illustration of the application of M-PVAC-IDA, adsorption of $\mathrm{Cu}$ (II) ion, which can be chelated by the metal chelating ligands of IDA in aqueous solution was performed. Adsorption isotherms with $\mathrm{pH}$ values of 1,2 , and 4.5 at $25^{\circ} \mathrm{C}$ were established. It was found that the adsorption capacity is highest at $\mathrm{pH}$ value of 4.5 while decreases as the $\mathrm{pH}$ value decreases. Thus, the exhausted M-PVAC-IDA after removing $\mathrm{Cu}$ (II) ion at moderate $\mathrm{pH}$ value of 4.5 can be regenerated at low $\mathrm{pH}$ value of 1 .
\end{abstract}

(C) 2006 Elsevier B.V. All rights reserved.

Keywords: Magnetite; Micro-size magnetic polymer; Magnetic adsorbent; Adsorbent; Adsorption; Copper ion; Metal chelating ligand

\section{Introduction}

Adsorption process has been extensively examined for the elimination of the organic substances or heavy metal ions from water and waste water [1-17]. Most common absorbents are porous such as activated carbon, silicon dioxide, activated aluminum, and zeolite. The porous property of adsorbents can typically provide larger specific surface area. For example, the Brunaur-Emmett-Teller (BET) specific surface area $\left(S_{\mathrm{BET}}\right)$ of the activated carbon Calgon F-400 of mesh $12-40$ is as large

\footnotetext{
* Corresponding author. Tel.: +886 2 23638994; fax: +886 223638994.

E-mail address: cychang3@ntu.edu.tw (C.-Y. Chang).
}

as $1026 \mathrm{~m}^{2} \mathrm{~g}^{-1}$ [1]. However, its specific area of external surface $\left(S_{\mathrm{E}}\right)$ is as small as $0.00576 \mathrm{~m}^{2} \mathrm{~g}^{-1}$. Thus, adsorption sites of porous adsorbents are mainly located inside the pores. However, the pores are usually twisted and tortuous, resulting that the porous absorbents also exhibit some disadvantages of adsorption. One of main disadvantages is that it usually takes a long time to reach the adsorption equilibrium for the porous adsorbents caused by the resistance of pore diffusion. Apparently, the regeneration process of porous adsorbent is also difficult with a long regeneration time.

As the diameter of particles decreases down to few micrometers or less, then a larger value of $S_{\mathrm{E}}$ of the particles can be obtained [18]. Also, the resistance of pore diffusion decreases with reducing particle size as commonly known. For example, 
as $1 \mathrm{~g}$ resin with the density of $0.8 \mathrm{~g} \mathrm{~cm}^{-3}$ is synthesized to small particles of $100 \mathrm{~nm}$ diameter, the value $S_{\mathrm{E}}$ becomes as large as $75 \mathrm{~m}^{2} \mathrm{~g}^{-1}$ which is $1.3 \times 10^{4}$ times that of Calgon F-400 of mesh 12-14. The effect of particle size on the uptake rates of selenite and cadmium by two transition aluminas CP-5 and CP-100 was examined by Papelis et al. [13]. They reported that about $3 \mathrm{~h}$ were needed for equilibrium for CP-5 with mass mean particle diameter $\left(d_{\mathrm{w}}\right)$ of $9.1 \mu \mathrm{m}$ while several days were needed for CP-100 with $d_{\mathrm{w}}$ of $73.3 \mu \mathrm{m}$. Hence, the use of micro- or nano-size adsorbents can overcome the disadvantage of the conventional adsorption process which takes a longer time to reach equilibrium encountered by the porous adsorbents of particle size bearing with the resistance of pore diffusion. In addition, the polymer adsorbent of micro-size is usually non-porous [19], thus preventing the clog problem and having good regeneration ability. Furthermore, it is easy to apply the chemical modification to change the chemical characteristics of the adsorbent's surface $[14,19,20]$. Therefore, the surface modified absorbents can have higher affinity to some specific substances [21]. However, for the beneficial application of such tiny adsorbents, one should consider the recovery of absorbents from water after use. The particles of micro- or nano-size are too small to have good recovery efficiency via the conventional gravity deposition, centrifugal separation, or filtration processes. Thus, in the present study, the magnetic adsorbents of micro-size were synthesized so that a high gradient magnetic force field can be applied to separate, recover, and recycle them from water after the adsorption process [22]. Another advantage of the high gradient magnetic separation is that the non-magnetic impurities can be excluded during recovery of magnetic adsorbents [22]. Preparation and application of magnetic polymer adsorbents (MPAs) with several functional groups had been examined by many investigators [22-44].

$\mathrm{Cu}$ (II) ion of the aged pickling solution of the printed circuit board plant had been treated via precipitation method before, causing the sludge problem. Therefore, this study applied MPA to treat the aged pickling solution for removing the $\mathrm{Cu}(\mathrm{II})$ ion. The exhausted MPA can be separated from the solution via the magnetic separation method. The separated MPA can further be regenerated with recovering of adsorbed $\mathrm{Cu}(\mathrm{II})$ ion via proper methods. Thus, the objective of this study is to synthesize microsize MPA coupling with metal chelating ligands of iminodiacetic acid (IDA) which can chelate the $\mathrm{Cu}$ (II) ion and its application for the removal of $\mathrm{Cu}$ (II) ion for which the corresponding adsorption isotherms at various $\mathrm{pH}$ values have not been reported. The super-paramagnetic $\mathrm{Fe}_{3} \mathrm{O}_{4}$ noted as magnetite was prepared by the chemical co-precipitation method and then coated with polyvinyl acetate (PVAC) to form MPA of magnetitePVAC (M-PVAC) via the suspension polymerization with vinyl acetate (VAC) [27]. The sequential treatments of alcoholysis, epoxide activation, and coupling of IDA further yielded the MPAs of magnetite-polyvinyl alcohol (M-PVAL), magnetitepolyvinyl propenepoxide (M-PVEP), and magnetite-polyvinyl acetate-IDA (M-PVAC-IDA), respectively. The morphology, magnetic properties, and composition of nano-size magnetite and/or micro-size MPAs were characterized with transmission electron microscope (TEM) and scanning electron microscope
(SEM), physical property measurement system (PPMS), and Fourier transform infrared (FTIR) spectroscope, respectively [29]. Finally, the adsorption experiments of $\mathrm{Cu}$ (II) ion in aqueous solution were performed using the micro-size M-PVAC-IDA.

\section{Materials and procedures}

\subsection{Reagents and instruments}

Ammonia, ferric chloride $\left(\mathrm{FeCl}_{3} \cdot 6 \mathrm{H}_{2} \mathrm{O}\right)$, ferrous chloride $\left(\mathrm{FeCl}_{2} \cdot 4 \mathrm{H}_{2} \mathrm{O}\right)$, and methanol were purchased from Merck. Oleic acid, epichlorohydrin, divinylbenzene, and VAC were obtained from Aldrich. PVAL with molecular weight (MW) of 8000 was supplied by Nacalai Tesque of Japan. Methylene blue was provided by Showa Chemicals Inc. of Japan. Benzyl peroxide was given by First Chemical Co. Ltd. of Japan. IDA was purchased from Sigma. Cupric sulfate was supplied by Nihon Shiyaku Industries Ltd. of Japan. The morphologies of magnetite and M-PVAC were analyzed by TEM (Jeol JSM-1200EX II) and SEM (Hitachi, S-4700, Type II, Japan), respectively. The magnetic properties of M-PVAC were measured by PPMS (Quantum Design, model 6000). The $S_{\mathrm{BET}}$ was measured via Micromeritics (Autopore II, Model 9520). The bulk density ( $\left.\rho_{\mathrm{p}}\right)$, solid density $\left(\rho_{\mathrm{s}}\right)$, and porosity $\left(\varepsilon_{\mathrm{p}}\right)$ of M-PVAC-IDA were estimated using pycnometer. The surfaces of MPAs of M-PVAC, M-PVAL, MPVEP, and M-PVAC-IDA were characterized via FTIR (Bio-Rag, model: FTS-40). The concentration of $\mathrm{Cu}$ (II) ion was analyzed using atomic absorption spectrophotometer (AA) (Perkin Elmer AA700/800).

\subsection{Synthesis of magnetite (M)}

About $10 \mathrm{~g}$ ferrous chloride and $25 \mathrm{~g}$ ferric chloride were dissolved in $500 \mathrm{~mL}$ distilled water at $85^{\circ} \mathrm{C}$ and kept under an environment of nitrogen in a $1 \mathrm{~L}$ conical flask equipped with the electric heater, paddle stirrer, and inlet systems for the nitrogen gas and reactants. Aqueous ammonia of about $30 \mathrm{~mL} \mathrm{(25} \mathrm{vol. \%}$ $\mathrm{NH}_{3} \cdot \mathrm{H}_{2} \mathrm{O}$ ) was then quickly added to the aqueous solution, which was stirred with a mechanical paddle at $600 \mathrm{rpm}$. Immediately, the dispersion agent of oleic acid was slowly added to the magnetite suspension until there was a clear supernatant liquid appeared. The magnetite (noted as $M$ ) was thus obtained.

\subsection{Synthesis of magnetite-polyvinyl acetate polymer}

About $25 \mathrm{~g}$ PVAL was dissolved in $1000 \mathrm{~mL}$ distilled water at $60{ }^{\circ} \mathrm{C}$ in a $2 \mathrm{~L}$ cylindrical glass reactor equipped with the baffle-board, electric heater, paddle stirrer, thermometer, and inlet systems for the nitrogen gas and reactants. The aqueous solution was stirred with a mechanical paddle at $800 \mathrm{rpm}$ for $30 \mathrm{~min}$. About $15 \mathrm{~g}$ magnetite, $90 \mathrm{~mL} \mathrm{VAC}$, and $15 \mathrm{~mL}$ divinylbenzene were added into the aqueous solution.

The suspension polymerization reaction was carried out in the above glass reactor at $70^{\circ} \mathrm{C}$ for about $6 \mathrm{~h}$. The reacted mixture was cooled to $25^{\circ} \mathrm{C}$, yielding magnetite-polyvinyl acetate polymer. The resulting M-PVAC particles were thoroughly washed with deionized water. 


\subsection{Introducing functional groups into M-PVAC polymer}

After polymerization, three sequential procedures including alcoholysis, epoxide activation, and coupling of IDA were employed to introduce functional groups on the surface of superparamagnetic particles of M-PVAC, without demolishing the magnetite within the particles. The procedures then yielded the super-paramagnetic particles of M-PVAL, M-PVEP, and M-PVAC-IDA, respectively.

In the above procedures for the modification of M-PVAC with chelating ligands of IDA, about $5 \mathrm{~g}$ M-PVAC particles were suspended in $100 \mathrm{~mL}$ solution containing about $95 \mathrm{~mL}$ methanol and stirred at $700 \mathrm{rpm}$ for $6 \mathrm{~h}$. M-PVAL was then obtained. Five grams M-PVAL particles were subsequently added to $100 \mathrm{~mL}$ liquid containing $50 \mathrm{~mL}$ epichlorohydrin and $50 \mathrm{~mL}$ acetone. The reaction was carried out at $700 \mathrm{rpm}$ for $8 \mathrm{~h}$ yielding M-PVEP. Five grams M-PVEP particles were further mixed with $100 \mathrm{~mL}$ aqueous solution containing $10 \mathrm{~g}$ IDA and stirred at $700 \mathrm{rpm}$ for $8 \mathrm{~h}$. This then gave desired M-PVAC-IDA.

\subsection{Experimental procedures of adsorption}

Batch adsorption tests at controlled temperature of $25^{\circ} \mathrm{C}$ were carried out using 125-mL glass bottles with Teflon lined caps. For examination of the $\mathrm{pH}$ effects, the dosages of adsorbent M-PVAC-IDA of about 50-100 mg were used and added into $30 \mathrm{~mL}$ aqueous solutions with various initial concentrations of $\mathrm{Cu}(\mathrm{II})$ ion $\left(C_{0}\right)$ in the range of $5-1000 \mathrm{mg} \mathrm{L}^{-1}$. The $\mathrm{pH}$ value of the solution was adjusted via $0.5 \mathrm{M}$ buffer solution containing acetic acid and sodium acetate. Noting that the size of M-PVAC is about $500 \mathrm{~nm}$ to $2 \mu \mathrm{m}$ which is smaller than that of CP-5 of $9.1 \mu \mathrm{m}$ with equilibrium time of about $3 \mathrm{~h}$ [13], we would expect that the equilibrium time of present adsorption system would not take longer than several hours. However, in order to ensure the reach of equilibrium and for the convenient time schedule of experiments, the adsorption experiments were conducted in a thermostatic shaker under shaking speed of $120 \mathrm{rpm}$ for 2 days to attain the equilibrium of adsorption. The concentrations of $\mathrm{Cu}$ (II) ion in solution were analyzed using an atomic absorption spectrophotometer (Perkin Elmer AA700/800).

\section{Results and discussion}

\subsection{TEM analysis for magnetite}

Fig. 1 illustrates the TEM photograph of magnetite. It is seen that most $\mathrm{Fe}_{3} \mathrm{O}_{4}$ particles exhibit spherical, cubic, or octahedral shapes and have particle size of about $10 \mathrm{~nm}$. Thus, the magnetite was well prepared in nano-size via the chemical co-precipitation method employed in this study. The oleic acid coated on the nano-size magnetite resulted in its hydrophobic property. The long alkyls of oleic acid not only stabilized the $\mathrm{Fe}_{3} \mathrm{O}_{4}$ nanoparticles, preventing their coagulation, but also enhanced the affinity of the $\mathrm{Fe}_{3} \mathrm{O}_{4}$ nano-particles to the monomer in the polymerization.

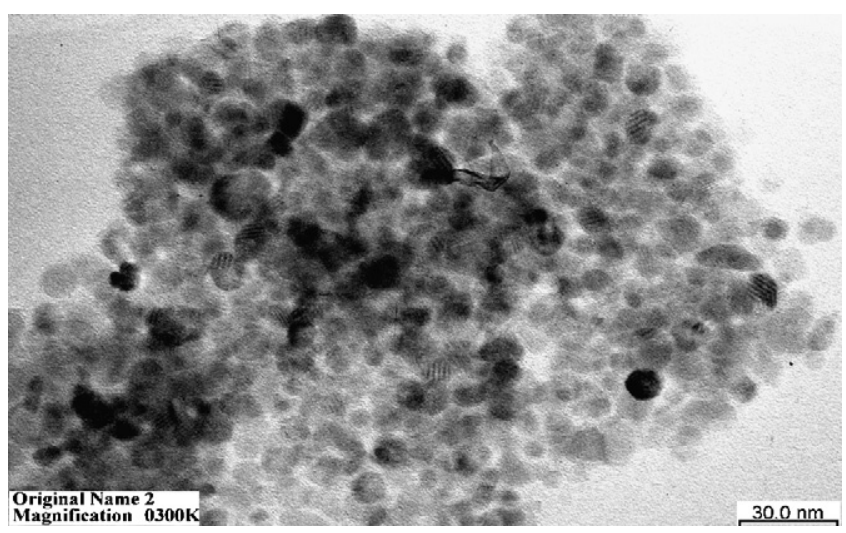

Fig. 1. Transmission electron micrograph (TEM) of $\mathrm{Fe}_{3} \mathrm{O}_{4}$ (magnetite, $M$ ) stabilized by oleic acid. Amplification: 300k.

\subsection{The characterization of M-PVAC, M-PVEP, and M-PVAC-IDA particles}

The $\mathrm{S}_{\mathrm{BET}}$ of M-PVAC-IDA was measured to be about $12.9 \mathrm{~m}^{2} \mathrm{~g}^{-1}$. Noting that the measured value of $\varepsilon_{\mathrm{p}}$ was nearly zero, we can say that the synthesized M-PVAC-IDA polymer is non-porous. Thus, the value of $S_{\mathrm{BET}}$ indeed is the specific area of external surface $S_{\mathrm{E}}$. The value of $S_{\mathrm{E}}$ of $12.90 \mathrm{~m}^{2} \mathrm{~g}^{-1}$ is about $2.2 \times 10^{3}$ times larger than that of Calgon F-400 of mesh 12-40. The density of M-PVAC-IDA is about $1.629 \mathrm{~g} \mathrm{~cm}^{-3}$. Other results such as those of SEM analysis, magnetization profile measurement, and FTIR analysis are as follows.

\subsubsection{SEM analysis for $M-P V A C$ particles}

Fig. 2 presents the SEM photograph of M-PVAC particles. The size of M-PVAC particles produced by the suspension polymerization is about $500 \mathrm{~nm}$ to $2 \mu \mathrm{m}$ and mostly about $1 \mu \mathrm{m}$ in number. Comparing the approximate sizes of magnetite and $\mathrm{M}$ PVAC particles of about $10 \mathrm{~nm}$ and $1 \mu \mathrm{m}$, respectively, we can note that the volume ratio of the former to the latter is estimated about $0.0001 \%\left(=\left((4 / 3) \pi(10 / 2)^{3}\right) /(4 / 3) \pi(1000 / 2)^{3}\right)$. It is noted that the particles shown in Figs. 1 and 2 are not very

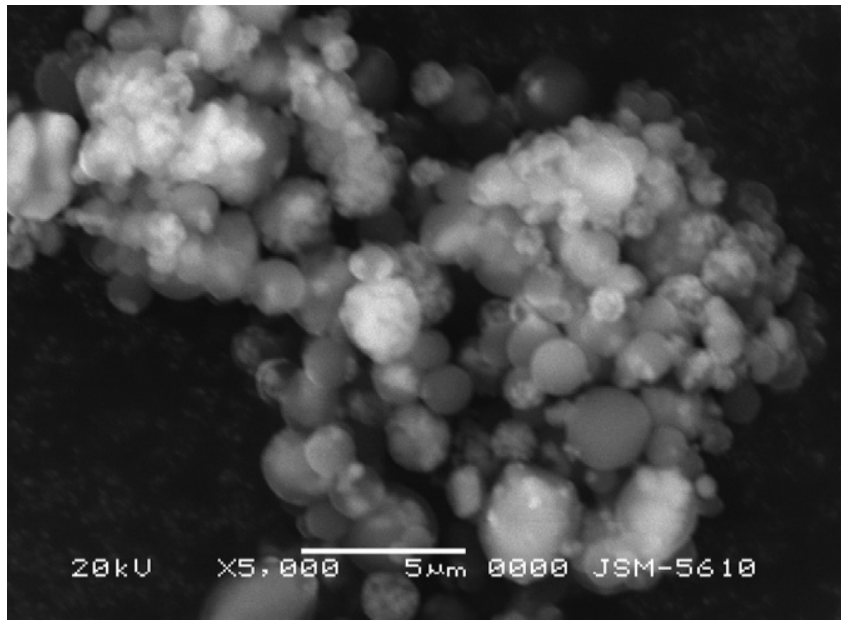

Fig. 2. Scanning electron micrograph (SEM) of magnetite-polyvinyl acetate (M-PVAC) polymer. Amplification: 5k. 


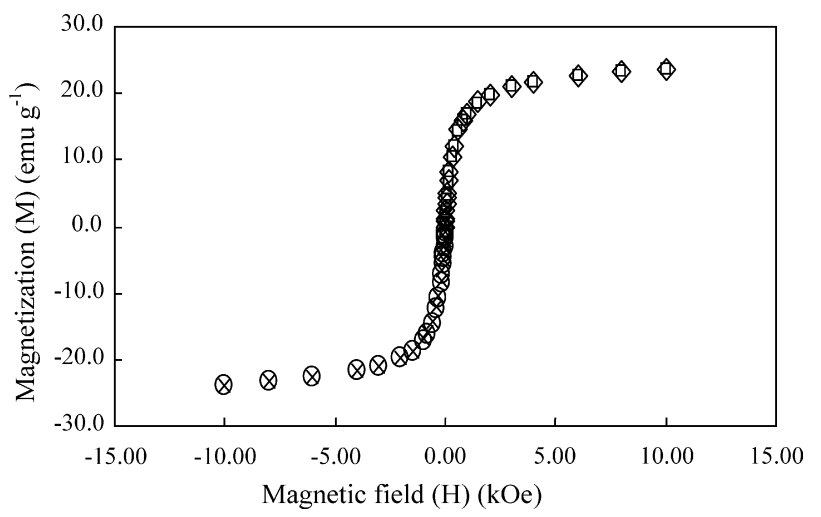

Fig. 3. The magnetization curve ( $M$ vs. $H$ ) of M-PVAC particles. $(\diamond) 0-10 \mathrm{kOe}$; ( $\square$ ) 10-0 kOe; $(\bigcirc) 0$ to $-10 \mathrm{kOe} ;(\times)-10-0 \mathrm{kOe}$.

spherical. Indeed, the estimated value based on the formula of the sphere was not precise. However, as a reference, it did indicate that the magnetites were well planted in PVAC to form M-PVAC. Thus, the magnetites were well coated with PVAC.

\subsubsection{The magnetization profile measurement for $M-P V A C$ particles}

The magnetization profiles of M-PVAC particles at $25^{\circ} \mathrm{C}$ are shown in Fig. 3. The results indicated that as the externally applied magnetic field $(H)$ was gradually reduced to its original situation, the magnetization profile of magnetic polymer particle of M-PVAC decreased along the original profile. The results also showed that there was no magnetic stagnation remained for MPVAC particles prepared in this study. As the externally applied magnetic field $H$ was reduced to zero, the residual magnetization as well as the coercive force was also decreased to zero. Thus, M-PVAC particles obtained in the present work were featured with super-paramagnetism.

The magnetite $\left(\mathrm{Fe}_{3} \mathrm{O}_{4}\right)$ enclosed in the polymer can be kept motionless without extra magnetization. It was mainly because the uniaxial anisotropy free energy $\left(K_{\mathrm{ai}} V_{\mathrm{sp}}\right)$ is less than the thermal energy $\left(k_{\mathrm{B}} T\right)$. This situation makes all the magnetization of atoms freely rotated in all $\mathrm{Fe}_{3} \mathrm{O}_{4}$ particles, resulting that the magnetization directions are randomly distributed. $K_{\mathrm{ai}}$ and $V_{\text {sp }}$ denote the uniaxial anisotropy constant (with unit of erg cm${ }^{-3}$ ) and super-paramagnetic particle volume $\left(\mathrm{cm}^{3}\right)$ and $k_{\mathrm{B}}$ is the Boltzmann's constant $\left(1.38 \times 10^{-16} \mathrm{ergs} \mathrm{K}^{-1}\right)$. Because of the super-paramagnetism, the mutual attraction among superparamagnetic polymer adsorbent particles without externally applied magnetic field would cause no agglomeration during usage.

\subsubsection{FTIR absorption spectra analyses for particles of $M-P V A L, M-P V E P$, and $M-P V A C-I D A$}

In order to introduce metal chelating ligands to M-PVAC, the M-PVAC were modified via alcoholysis, epoxide activation, and coupling of IDA. The raw M-PVAC was analyzed via the FTIR absorption spectrum as shown in Fig. 4. The spectrum obviously indicated a sorption peak of ester bond of $\mathrm{C}=\mathrm{O}$ of $\mathrm{PVAC}$ at the wavenumber of $1717 \mathrm{~cm}^{-1}$.

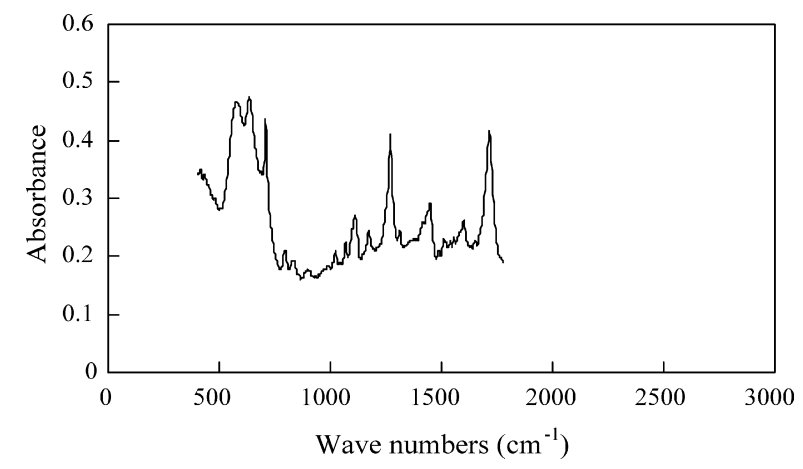

Fig. 4. Fourier transform infraed (FTIR) absorption spectrum of M-PVAC.<smiles>CCCCCC(CC(C)(C)C)OC(C)=O</smiles>

The magnetic-polyvinyl alcohol can be obtained from the alcoholysis of M-PVAC. As shown in Fig. 5, the sorption peak of ester bond of $\mathrm{C}=\mathrm{O}$ of PVAC had been remarkably weakened after alcoholysis. At the wavenumber of $1455 \mathrm{~cm}^{-1}$, the sorption peak of $\mathrm{CH}-\mathrm{OH}$ appeared, reflecting the alcoholysis of M-PVAC to M-PVAL.

After the M-PVAL was activated by epichlorohydrin, the magnetic-polyvinyl propenepoxide can then be obtained. As illustrated in Fig. 6, the sorption peak of $\mathrm{CH}-\mathrm{OH}$ located at wavenumber of $1455 \mathrm{~cm}^{-1}$ had been obviously weakened. At the wavenumbers of 1072 and $849 \mathrm{~cm}^{-1}$, the sorption peaks of $\mathrm{C}-\mathrm{O}$ bond and expoxide appeared, indicating the expoxide activation of M-PVAL to M-PVEP.

The coupling of IDA to M-PVEP yielded M-PVAC-IDA. Noting Fig. 7, we can see that there obviously existed a sorption peak of tertitary-amine at the wavenumber of $1112 \mathrm{~cm}^{-1}$. Also, at the wavenumbers of 1393 and $1605 \mathrm{~cm}^{-1}$, the sorption peaks of $-\mathrm{COO}^{-}$appeared. All these indicated that IDA had been successfully linked to the surface of M-PVAC. The functional groups of metal chelating ligands of IDA on M-PVAC provide good affinity of metal ions such as $\mathrm{Cu}(\mathrm{II})$.

In summary, the above results revealed that the magnetites were well coated with PVAC and incorporated with alcoholysis,

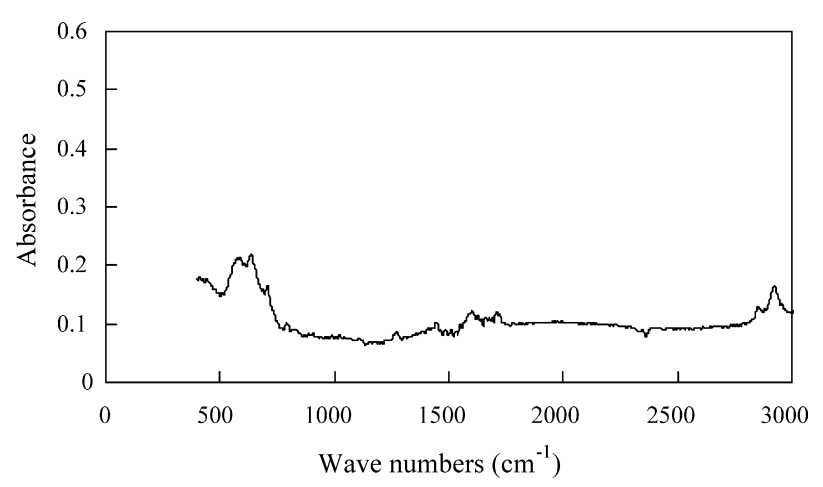

Fig. 5. FTIR absorption spectrum of magnetite-polyvinyl alcohol (M-PVAL). $-\left[\mathrm{CH}_{2} \mathrm{CH}\right]_{n}$

PVAL: $\quad \mathrm{OH}$ 


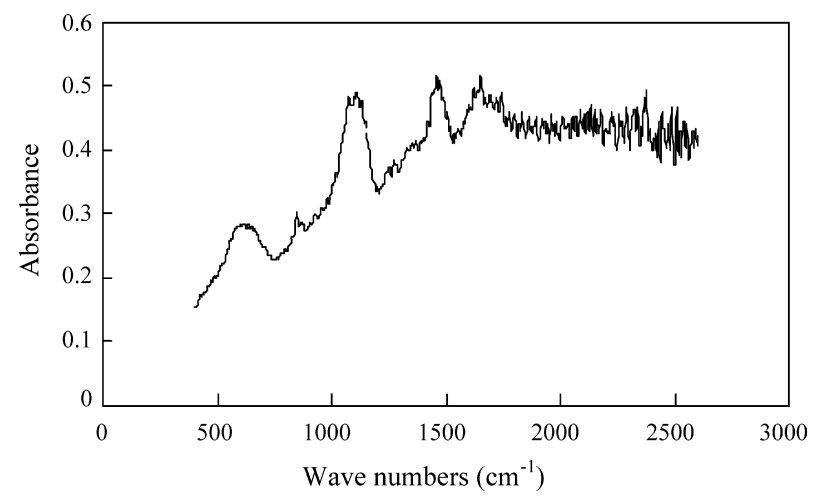

Fig. 6. FTIR absorption spectrum of magnetite-polyvinyl propenepoxide (MPVEP). PVEP: $\quad \mathrm{OCH}_{2} \mathrm{CH}-\mathrm{CH}_{2}$.

epoxide activation, and coupling of IDA. Also the particle size of resulted M-PVAC polymer is as small as of $500 \mathrm{~nm}$ to $2 \mu \mathrm{m}$.

\subsection{The removal of $\mathrm{Cu}(\mathrm{II})$ ion using adsorbent of M-PVAC-IDA particles}

The adsorption experiments of $\mathrm{Cu}$ (II) ion as the pollutant in aqueous solution were performed using M-PVAC-IDA as the magnetic adsorbent. Solutions containing $\mathrm{Cu}$ (II) ion with concentrations in the range of $5-1000 \mathrm{mg} \mathrm{L}^{-1}$ were prepared according to the characteristics of the aged pickling solution of the printed circuit board plant. The results of the effects of $\mathrm{pH}$ on the adsorption and the corresponding adsorption isotherms were discussed as follows.

\subsubsection{Effects of $p H$}

Fig. 8 presents the influence of $\mathrm{pH}$ on the equilibrium behavior of adsorption of $\mathrm{Cu}$ (II) ion using M-PVAC-IDA. The values of $\mathrm{pH}$ were controlled below 5 because the solubility product of the precipitation of $\mathrm{Cu}$ (II) is low as $\mathrm{pH}$ value is above 5 , facing the precipitation problem. The results indicated that the adsorption capacities are higher at higher $\mathrm{pH}$ values and $\mathrm{Cu}$ (II) ion concentrations of solution. This may be attributed to the forma-

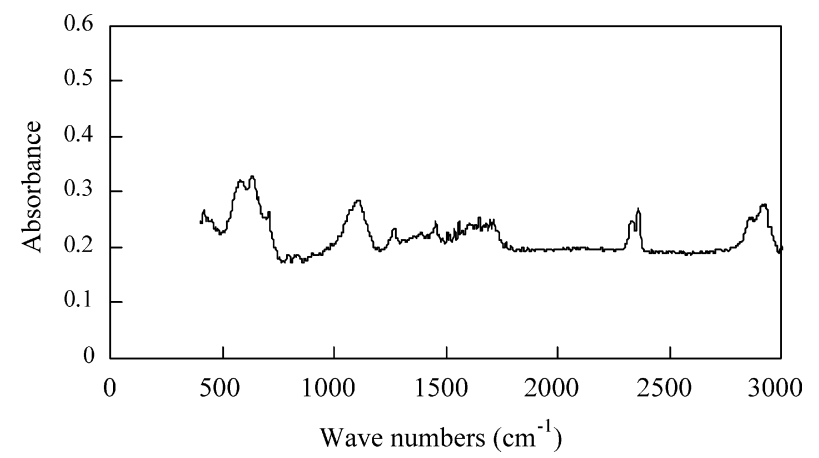

Fig. 7. FTIR absorption spectrum of magnetite-polyvinyl acetate-IDA (M-

$$
\text { PVAC-IDA). PVAC-IDA: } \underset{\mathrm{OH}}{\mathrm{OCH}_{2} \mathrm{CHCH}_{2} \mathrm{~N}>\mathrm{CH}_{2} \mathrm{COONa}} \text {. }
$$

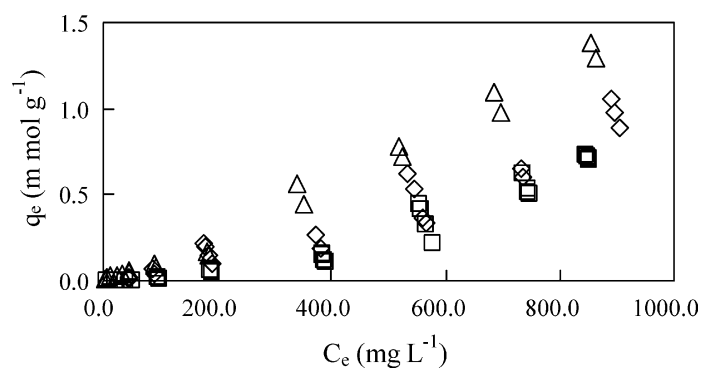

Fig. 8. $q_{\mathrm{e}}$ vs. $C_{\mathrm{e}}$ for adsorption of $\mathrm{Cu}(\mathrm{II})$ ion onto M-PVAC-IDA at $25^{\circ} \mathrm{C} . C_{\mathrm{e}}$, equilibrium concentration of $\mathrm{Cu}(\mathrm{II})$ in solution $\left(\mathrm{mg} \mathrm{L}^{-1}\right) . q_{\mathrm{e}}$, equilibrium $\mathrm{Cu}$ (II) immoblized on adsorbent phase $\left(\mathrm{mmol} \mathrm{g}^{-1}\right) .(\triangle),(\diamond)$ and $(\square): \mathrm{pH} 4.5,2$, and 1 .

tion of surface complexes between $\mathrm{Cu}(\mathrm{II})$ ion and the chelating ligands of M-PVAC-IDA. The adsorption of the metal cation on adsorbent also depends on the nature of the adsorbent surface and species distribution of the cation. At low $\mathrm{pH}$ values and $\mathrm{Cu}$ (II) ion concentrations, the dominant cation is hydrogen ion. Therefore, the adsorption of $\mathrm{Cu}$ (II) ion is not favorable at low $\mathrm{pH}$ value of 1 .

\subsubsection{Adsorption isotherm}

The equilibrium behavior of adsorption of $\mathrm{Cu}$ (II) ion on M-PVAC-IDA can be mathematically expressed via proper equations of adsorption isotherms. Two common adsorption isotherms, namely, Langmuir and Freundlich isotherms, were tested for the fitness as described below.

The Freundlich adsorption isotherm is expressed as

$q_{\mathrm{e}}=\frac{n_{\mathrm{A}}}{m_{\mathrm{s}}}=k_{\mathrm{F}} C_{\mathrm{e}}^{1 / n_{\mathrm{F}}}$

The logarithmic form of the equation becomes

$\log q_{\mathrm{e}}=\log k_{\mathrm{F}}+\frac{1}{n_{\mathrm{F}}} \log C_{\mathrm{e}}$

The Freundlich adsorption isotherm represents the equilibrium relationship between the amount of $\mathrm{Cu}$ (II) ion $\left(n_{\mathrm{A}}, \mathrm{mmol}\right)$ adsorbed per unit mass of adsorbent $\left(m_{\mathrm{S}}, \mathrm{g}\right)\left(q_{\mathrm{e}}=n_{\mathrm{A}} / m_{\mathrm{S}}\right)$ and the concentration of $\mathrm{Cu}(\mathrm{II})$ ion $\left(C_{\mathrm{e}}, \mathrm{mg} \mathrm{L}^{-1}\right) . k_{\mathrm{F}}$ and $n_{\mathrm{F}}$ are constants representing the adsorption capacity and intensity of adsorption, respectively. The value of capacity $q_{\mathrm{e}}$ at $C_{\mathrm{e}}$ can be calculated by the equations below.

$q_{\mathrm{e}}=\frac{\left(C_{0}-C_{\mathrm{e}}\right) V_{\mathrm{L}} / M_{\mathrm{A}}}{m_{s}}$

Detailed description of the above notations are summarized as follows.

$C_{0}$ : initial concentration of $\mathrm{Cu}(\mathrm{II})$ ion in solution $\left(\mathrm{mg} \mathrm{L}^{-1}\right)$

$C_{\mathrm{e}}$ : equilibrium concentration of $\mathrm{Cu}(\mathrm{II})$ ion in solution $\left(\mathrm{mg} \mathrm{L}^{-1}\right)$

$V_{\mathrm{L}}$ : volume of solution $(0.03 \mathrm{~L}$ in this study)

$M_{\mathrm{A}}$ : the atomic weight of copper (63.546)

$m_{\mathrm{s}}$ : mass of solid adsorbent ( $0.05 \mathrm{~g}$ in this study)

$n_{\mathrm{A}}$ : equilibrium amount of $\mathrm{Cu}$ (II) ion in solid adsorbent (mmol) $q_{\mathrm{e}}: n_{\mathrm{A}} / m_{\mathrm{s}}$, equilibrium concentration of $\mathrm{Cu}(\mathrm{II})$ ion in solid adsorbent $\left(\mathrm{mmol} \mathrm{g}^{-1}\right)$

$k_{\mathrm{F}}$ and $n_{\mathrm{F}}$ : parameters of Freundlich equation (Eq. (1)). 
Table 1

Parameters of adsorption isotherms for adsorption of $\mathrm{Cu}(\mathrm{II})$ ion onto M-PVAC-IDA with pH 4.5 at $25^{\circ} \mathrm{C}$

\begin{tabular}{|c|c|c|c|c|}
\hline Adsorption isotherm & Equation & Parameter & Value of parameter & $r^{2}$ \\
\hline Langmuir & $q_{\mathrm{e}}=\frac{n_{\mathrm{A}}}{m_{\mathrm{s}}}=\frac{K_{\mathrm{L}} q_{\mathrm{L}} C_{\mathrm{e}}}{1+K_{L} C_{\mathrm{e}}}$ & $\begin{array}{l}K_{\mathrm{L}}\left(\mathrm{L} \mathrm{mg}^{-1}\right) \\
q_{\mathrm{L}}\left(\mathrm{mmol} \mathrm{g}^{-1}\right)\end{array}$ & $\begin{array}{l}4.029 \mathrm{E}-02 \\
1.205 \mathrm{E}-01\end{array}$ & 0.916 \\
\hline Freundlich & $q_{\mathrm{e}}=\frac{n_{\mathrm{A}}}{m_{\mathrm{s}}}=k_{\mathrm{F}} C_{\mathrm{e}}^{1 / n_{\mathrm{F}}}$ & $\begin{array}{l}k_{\mathrm{F}}\left(\mathrm{mmol} \mathrm{g}^{-1}\right)\left(\mathrm{mg} \mathrm{L}^{-1}\right)^{-0.8237} \\
n_{\mathrm{F}}(\text { dimensionless })\end{array}$ & $\begin{array}{l}3.532 \mathrm{E}-03 \\
1.214\end{array}$ & 0.944 \\
\hline
\end{tabular}

$q_{\mathrm{e}}, C_{\mathrm{e}}$ : equilibrium concentrations of $\mathrm{Cu}(\mathrm{II})$ on solid $\left(n_{\mathrm{A}} / m_{\mathrm{s}}\right)$ and in solution $\left(\mathrm{mg} \mathrm{L}^{-1}\right) ; n_{\mathrm{A}}, m_{\mathrm{s}}$ : masses of Cu(II) and solid with units of mmol and g.

Table 2

Parameters of adsorption isotherms for adsorption of $\mathrm{Cu}(\mathrm{II})$ ion onto M-PVAC-IDA with pH 2 at $25^{\circ} \mathrm{C}$

\begin{tabular}{|c|c|c|c|c|}
\hline Adsorption isotherm & Equation & Parameter & Value of parameter & $r^{2}$ \\
\hline \multirow[t]{2}{*}{ Freundlich } & \multirow[t]{2}{*}{$q_{\mathrm{e}}=\frac{n_{\mathrm{A}}}{m_{\mathrm{s}}}=k_{\mathrm{F}} C_{\mathrm{e}}^{1 / n_{\mathrm{F}}}$} & $k_{\mathrm{F}}\left(\mathrm{mmol} \mathrm{g}^{-1}\right)\left(\mathrm{mg} \mathrm{L}^{-1}\right)^{-1.2558}$ & $1.754 \mathrm{E}-04$ & \multirow[t]{2}{*}{0.941} \\
\hline & & $n_{\mathrm{F}}$ (dimensionless) & $7.963 \mathrm{E}-01$ & \\
\hline
\end{tabular}

$q_{\mathrm{e}}, C_{\mathrm{e}}, n_{\mathrm{A}}, m_{\mathrm{s}}:$ as specified in Table 1.

Table 3

Parameters of adsorption isotherms for adsorption of $\mathrm{Cu}$ (II) ion onto M-PVAC-IDA with pH 1 at $25^{\circ} \mathrm{C}$

\begin{tabular}{|c|c|c|c|c|}
\hline Adsorption isotherm & Equation & Parameter & Value of parameter & $r^{2}$ \\
\hline Freundlich & $q_{\mathrm{e}}=\frac{n_{\mathrm{A}}}{m_{\mathrm{s}}}=k_{\mathrm{F}} C_{\mathrm{e}}^{1 / n_{\mathrm{F}}}$ & $\begin{array}{l}k_{\mathrm{F}}\left(\mathrm{mmol} \mathrm{g}^{-1}\right)\left(\mathrm{mg} \mathrm{L}^{-1}\right)^{-1.7449} \\
n_{\mathrm{F}}(\text { dimensionless })\end{array}$ & $\begin{array}{l}5.146 \mathrm{E}-06 \\
5.731 \mathrm{E}-01\end{array}$ & 0.982 \\
\hline
\end{tabular}

$q_{\mathrm{e}}, C_{\mathrm{e}}, n_{\mathrm{A}}, m_{\mathrm{s}}:$ as specified in Table 1.

Parameters of Freundlich adsorption isotherms at $\mathrm{pH}$ values of 4.5, 2, and 1 are listed in Tables $1-3$, respectively. The corresponding plots of $\log q_{\mathrm{e}}$ versus $\log C_{\mathrm{e}}$ are shown in Fig. 9. At $\mathrm{pH}$ values of $4.5,2$, and 1 , the correlation coefficients $r^{2}$ of regression equations were $0.944,0.941$, and 0.982 , respectively, indicating satisfactory fittings of curves.

The values of $k_{\mathrm{F}}$ in Freundlich isotherms at $\mathrm{pH}$ values of 4.5, 2 , and 1 were $3.532 \mathrm{E}-03,1.754 \mathrm{E}-04$, and $5.146 \mathrm{E}-06$, while the corresponding values of adsorption intensity $n_{\mathrm{F}}$ were 1.214 , 0.796 , and 0.573 , respectively. A higher value of $k_{\mathrm{F}}$ indicated a higher affinity for copper on M-PVAC-IDA. Further, the value of $n_{\mathrm{F}}$ was great than 1 for the case at $\mathrm{pH} 4.5$, indicating favorable adsorption. At $\mathrm{pH} 1$, the value of $n_{\mathrm{F}}$ was as law as 0.573 , reflecting unfavorable adsorption. Thus, M-PVAC-IDA can be used for the adsorption removal of $\mathrm{Cu}$ (II) ion from aqueous solution

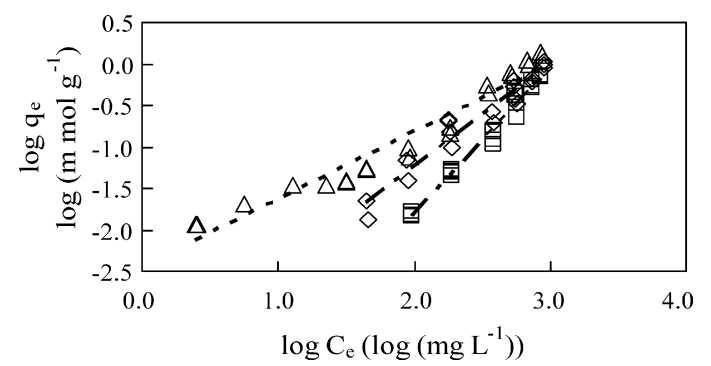

Fig. 9. Freundlich isotherms for adsorption of $\mathrm{Cu}$ (II) ion onto M-PVAC-IDA at $25^{\circ}$ C. $C_{\mathrm{e}}, q_{\mathrm{e}}$ : as specified in Fig. 8 . Symbols, lines: experiments, prediction. $(\triangle)$ and $(--),(\diamond)$ and $(---),(\square)$ and $(---)$ : $\mathrm{pH} 4.5,2,1$, and $r^{2}=0.944,0.941$, 0.982 . at higher $\mathrm{pH}$ values (say, 4.5), while regenerated at lower $\mathrm{pH}$ values (say, 1).

The Langmuir equation is

$q_{\mathrm{e}}=\frac{n_{\mathrm{A}}}{m_{\mathrm{s}}}=\frac{q_{\mathrm{L}} K_{\mathrm{L}} C_{\mathrm{e}}}{1+K_{\mathrm{L}} C_{\mathrm{e}}}$

where $q_{\mathrm{e}}$ and $C_{\mathrm{e}}$ are the equilibrium concentrations of adsorbate on solid and in liquid, respectively, as noted above. $q_{\mathrm{L}}$ and $K_{\mathrm{L}}$ represent the monolayer adsorption capacity and equilibrium constant of adsorption, respectively. Eq. (4) can be rearranged as

$\frac{1}{q_{\mathrm{e}}}=\frac{1}{q_{\mathrm{L}}}+\left(\frac{1}{K_{\mathrm{L}} q_{\mathrm{L}}}\right)\left(\frac{1}{C_{\mathrm{e}}}\right)$

From the linear plots of $1 / q_{\mathrm{e}}$ versus $1 / C_{\mathrm{e}}$, we can obtain the parameters of Eq. (4). However, it is noted the adsorption of $\mathrm{Cu}$ (II) ion on M-PVAC-IDA obeyed the Langmuir isotherm with positive values of $q_{\mathrm{L}}$ and $K_{\mathrm{L}}$ only for the case with $\mathrm{pH}$ value of 4.5 in this study. At $\mathrm{pH} 2$ and 1 , the values of $q_{\mathrm{L}}$ derived from the simulation results of Langmuir isotherm were negative and irrational for physical interpretation. Thus, the Langmuir equation was not applicable for the cases at $\mathrm{pH} 2$ and 1 for the adsorption of $\mathrm{Cu}$ (II) ion on M-PVAC-IDA in this study. At $\mathrm{pH} 4.5$, the Langmuir isotherm was applicable with monolayer adsorption capacity $q_{\mathrm{L}}$ of $121 \mu \mathrm{mol} \mathrm{g}^{-1}$ as listed in Table 1 . The corresponding plot of $1 / q_{\mathrm{e}}$ versus $1 / C_{\mathrm{e}}$ is shown in Fig. 10 indicating satisfactory agreement.

Some synthesized polymer adsorbents such as methyl methacrylate-co-glycidyl methacrylate copolymer coupling 
Table 4

Parameters of Langmuir and Freundlich isotherms of copper adsorption on different adsorbents

\begin{tabular}{|c|c|c|c|c|c|}
\hline \multirow[t]{2}{*}{ Adsorbent } & \multicolumn{2}{|l|}{ Langmuir } & \multicolumn{2}{|l|}{ Freundlich } & \multirow[t]{2}{*}{ Refs. } \\
\hline & $\overline{K_{\mathrm{L}}\left(\mathrm{L} \mathrm{mg}^{-1}\right)}$ & $q_{\mathrm{L}}\left(\mathrm{mmol} \mathrm{g}^{-1}\right)$ & $\overline{k_{\mathrm{F}}\left(\mathrm{mmol} \mathrm{g}^{-1}\right)}$ & $n_{\mathrm{F}}$ & \\
\hline M-PVAC-IDA & 0.0403 & 0.121 & 0.00353 & 1.214 & This study (pH 4.5) \\
\hline Dowex $50 \mathrm{~W}$ resin & 0.0150 & 0.35 & 2.6903 & 0.423 & Pehlivan and Altun [45] \\
\hline Cellulosic resin & 0.2239 & 1.29 & 4.02 & 3.063 & Zhao et al. [46] \\
\hline Dowex 50X8-200 & 0.258 & 0.0164 & - & - & Sing and $\mathrm{Yu}$ [47] \\
\hline Polysaccharide cellulose & - & $1.24 \times 10^{-4}$ & - & - & Chen et al. [48] \\
\hline
\end{tabular}

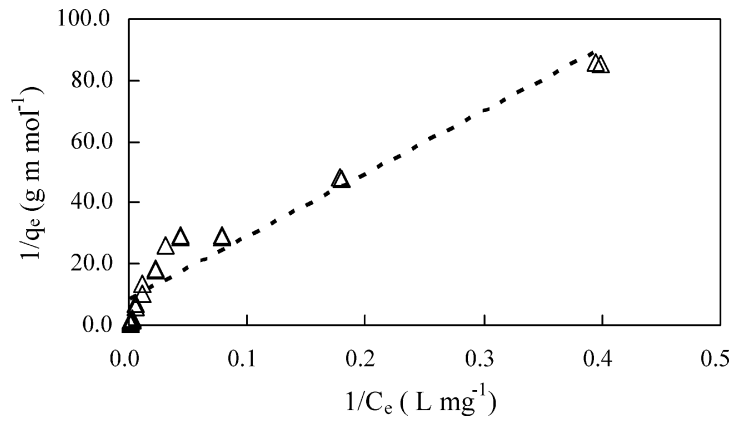

Fig. 10. Langmuir isotherm for adsorption of $\mathrm{Cu}(\mathrm{II})$ ions onto M-PVAC-IDA with $\mathrm{pH} 4.5$ at $25^{\circ} \mathrm{C}$. $C_{\mathrm{e}}, q_{\mathrm{e}}$ : as specified in Fig. 8. Symbol, line: experiment, prediction. $r^{2}=0.91$.

with IDA (denoted as MMA-GMA-IDA) [19] and magnetic polymethyl methacrylate incorporating with ethylene diamine (denoted as mPMMA-EDA) [28] had been applied for the adsorption of $\mathrm{Cu}$ (II) ion. For MMA-GMA-IDA, about $0.0127 \mathrm{mmol} \mathrm{g}^{-1}$ of $\mathrm{Cu}(\mathrm{II})$ ion was chelated on the IDA-bound particles [19]. The masses of $\mathrm{Cu}(\mathrm{II})$ ion adsorbed on mPMMAEDA were about $0.09-0.201 \mathrm{mmol} \mathrm{g}^{-1}$ for $C_{0}$ in the range of $5-60 \mathrm{mg} \mathrm{L}^{-1}$ [28]. As for the present system at $\mathrm{pH} 4.5$ with $C_{0}$ of $5-1000 \mathrm{mg} \mathrm{L}^{-1}$, about $0.012-1.334 \mathrm{mmol} \mathrm{g}^{-1}$ of $\mathrm{Cu}$ (II) ion were chelated on M-PVAC-IDA. Thus, the $\mathrm{Cu}(\mathrm{II})$ ion uptakes of M-PVAC-IDA are comparable to those of MMA-GMA-IDA and mPMMA-EDA. As for the success of adsorption of $\mathrm{Cu}(\mathrm{II})$ ion on M-PVAC-IDA, the adsorption efficiencies $\left(\eta=\left(C_{0}-C_{\mathrm{e}}\right) / C_{0}\right.$, in percent of adsorption, \%) at $\mathrm{pH} 4.5$ were about 49.6 and 14.1 for $C_{0}$ of 5 and $1000 \mathrm{mg} \mathrm{L}^{-1}$, respectively.

The calculated parameters of adsorption isotherms were further compared to those of literature as listed in Table 4. The orders of magnitude of $q_{\mathrm{L}}$ are cellulosic resin $(\mathrm{CR})>$ Dowex $50 \mathrm{~W}$ resin $(\mathrm{D}-50 \mathrm{~W})>\mathrm{M}-\mathrm{PVAC}-\mathrm{IDA}>$ Dowex 50X8-200 (D$50 \mathrm{X})>$ polyscaccharides cellulose $(\mathrm{PC})$. As for $K_{\mathrm{L}}$, the orders are D-50X $>$ CR $>$ M-PVAC-IDA $>$ D-50 W. Further, the orders of $n_{\mathrm{F}}$ are CR $>$ M-PVAC-IDA $>$ D-50 W. Thus, the adsorption ability of $\mathrm{Cu}(\mathrm{II})$ ion via the M-PVAC-IDA is moderate as compared to the other four polymer adsorbents discussed.

\section{Conclusions}

This study conducted the synthesis of micro-size magnetic polymer adsorbent and its application for the removal of $\mathrm{Cu}$ (II) ions. Suspension polymerization was employed as an effective way for the synthesis of M-PVAC-IDA polymer. Characteristics of the prepared polymer were also examined. Some conclusions may be drawn as follows.

(1) The production yield of M-PVAC was quite high with excellent narrow particle size distribution via suspension polymerization. Most of the particles are about $500 \mathrm{~nm}$ to $2 \mu \mathrm{m}$ in diameter in term of number with the average value of about $1 \mu \mathrm{m}$.

(2) Based on the results of FTIR absorption spectrum analysis, the synthesized M-PVAC-IDA polymer did contain functional groups of metal chelating ligands of IDA, which can chelate metal ions such as $\mathrm{Cu}$ (II).

(3) The magnetization profile measurement indicated that the synthesized M-PVAC-IDA polymer was featured with the magnetization profiles of no magnetic stagnation under normal ambient temperature. As the externally applied magnetic field $H$ was zero, the residual magnetization magnitude $M_{\mathrm{r}}$ and coercive force $H_{\mathrm{c}}$ were equal to zero. Thus, the prepared M-PVAC-IDA polymer exhibited superparamagnetism under normal ambient temperature.

(4) For the adsorption of $\mathrm{Cu}$ (II) ion via M-PVAC-IDA polymer adsorbent at $\mathrm{pH} 4.5$, the monolayer adsorption capacity is $0.121 \mathrm{mmol} \mathrm{g}^{-1}$. Under the experimental conditions of this study with $\mathrm{Cu}(\mathrm{II})$ ion concentrations in $5-1000 \mathrm{mg} \mathrm{L}^{-1}$ and $\mathrm{pH}$ values in $1-4.5$, the adsorption behaviors can be satisfactorily described via the Freundlich isotherm. The condition at $\mathrm{pH} 4.5$ gave highest adsorption capacity. The case at $\mathrm{pH} 1$ was unfavorable for adsorption. Thus, M-PVAC-IDA polymer adsorbent can be used to remove $\mathrm{Cu}$ (II) ion via adsorption at $\mathrm{pH} 4.5$ while regenerated via desorption at $\mathrm{pH} 1$.

\section{Acknowledgement}

This study was supported by the National Science Council of Taiwan under Grant No. NSC 92-2211-E-002-033.

\section{References}

[1] C.F. Chang, C.Y. Chang, W.T. Tsai, Adsorption equilibrium of polyethylene glycol in the copper electroplating solution on activated carbon, J. Colloid Interface Sci. 232 (2000) 207-209.

[2] C.F. Chang, C.Y. Chang, W. Höll, Adsorption behavior of 2naphthalenesulfonate on activated carbon form aqueous system, Ind. Eng. Chem. Res. 42 (2003) 6904-6910. 
[3] C.F. Chang, C.Y. Chang, W. Höll, Investigating the adsorption of 2mercaptothiazoline on activated carbon from aqueous system, J. Colloid Interface Sci. 272 (2004) 52-58.

[4] C.F. Chang, C.Y. Chang, W. Höll, M. Ulmer, Y.H. Chen, H.J. Groß, Adsorption kinetics of polyethylene glycol from aqueous solution onto activated carbon, Water Res. 38 (2004) 2559-2570.

[5] C.F. Chang, C.Y. Chang, K.H. Chen, W.T. Tsai, J.L. Shie, Y.H. Chen, Adsorption of naphthalene on zeolite from aqueous solution, J. Colloid Interface Sci. 266 (2003) 273-279.

[6] C.Y. Chang, W.T. Tsai, C.H. Ing, C.F. Chang, Adsorption of polyethylene glycol (PEG) from aqueous solution onto hydrophobic zeolite, J. Colloid Interface Sci. 277 (2004) 29-34.

[7] C.T. Chiou, Environmental partitioning and contamination of organic compounds, J. Chin. Inst. Environ. Eng. 13 (2003) 1-6.

[8] W. Den, H.C. Liu, S.F. Chan, K.T. Kin, C.P. Huang, Adsorption of phthalate esters with multiwalled carbon nanotubes and its application, J. Environ. Eng. Manag. (formerly, J. Chin. Inst. Environ. Eng.) 16 (2006) 275-282.

[9] P.E. Diaz-Flores, R. Leyva-Romos, J.R. Rangel-Mendez, M.M. Ortiz, R.M. Guerrero-Coronado, J. Mendoza-Barron, Adsorption of 2,4dichlorophenoxyacetic acid from aqueous solution on activated carbon cloth, J. Environ. Eng. Manag. (formerly, J. Chin. Inst. Environ. Eng.) 16 (2006) 249-257.

[10] W.H. Höll, C. Bartosch, X. Zhao, S. He, Elimination of trace heavy metals from drinking and ground water by means of weakly basic anion exchangers, J. Chin. Inst. Environ. Eng. 13 (2003) 77-85.

[11] C.K. Jain, I. Ali, Adsorption of cadmium on riverine sediments: quantitative treatment of the large particles, Hydrological Process. 14 (2000) 261-270.

[12] C. Namasivayam, K. Prathap, Removal of thiocyanate by industrial solid waste $\mathrm{Fe}(\mathrm{III}) / \mathrm{Cr}$ (III) hydroxide: kinetic and equilibrium studies, J. Environ. Eng. Manng. (formerly, J. Chin. Inst. Environ. Eng.) 16 (2006) 267-274.

[13] C. Papelis, P.V. Roberts, J.O. Leekie, Modeling the rate of cadmium and selenite adsorption on micro- and mesoporous transition aluminas, Environ. Sci. Technol. 29 (1995) 1099-1108.

[14] C.C. Wang, C.Y. Chen, C.Y. Chang, Synthesis of chelating resins with iminodiacetic acid and its wastewater treatment application, J. Appl. Polym. Sci. 84 (2002) 1353-1362.

[15] G.S. Wang, Effects of natural organic matter on adsorption capacity for atrazine by activated carbon, J. Chin. Inst. Environ. Eng. 15 (2005) 81-89.

[16] C.H. Wu, C.F. Lin, S.L. Lo, Modeling competitive adsorption of chromate, sulfate, and selenate on $\gamma-\mathrm{Al}_{2} \mathrm{O}_{3}$ : comparison between the triple-layer model and a Freundlich-type multi-component isotherm, J. Chin. Inst. Environ. Eng. 13 (2003) 87-94.

[17] C.C. Wu, Y.C. Wang, T.F. Lin, H.L. Tsao, P.C. Chen, Removal of arsenic from waste water using surface modified diatomite, J. Chin. Inst. Environ. Eng. 15 (2005) 255-261.

[18] A. Navrotsky, Nanomaterial in the environment, agriculture, and technology (NEAT), J. Nanopart. Res. 2 (2000) 321-323.

[19] H.A. Tsai, C.H. Chen, W.C. Lee, Influence of surface hydrophobic groups on the adsorption of proteins onto nonporous polymeric particles with immoblized metal ions, J. Colloid Interface Sci. 240 (2001) 379-383.

[20] C.Y. Chen, C.Y. Chen, Study on stability constants of polymer-bound imino diacetate-type chelating agents with some transition-metal ions, J. Appl. Polym. Sci. 86 (2002) 1986-1994.

[21] D.C. Sherrington, P. Hodge, Syntheses and Separation Using Functional Polymers, John Wiley \& Sons, New York, NY, USA, 1988.

[22] S. Miltenyi, Magnetic separation apparatus, US Patent 5,711,871 (1998).

[23] G. Blankenstein, Microfabricated Flow System for Magnetic Cell and Particle Separation in Scientific and Clinical Applications of Magnetic Carriers, Plenum Press, New York, NY, USA, 1997.

[24] M.A. Burns, D.J. Graves, Application of magnetically stablized fluidized beds to bioseperations, React. Polym. 6 (1987) 45-50.
[25] J.J. Chalmers, M. Zborowski, L.P. Sun, L. Moore, Flow through immunomagnetic cell separation, Biotechnol. Prog. 14 (1998) 141-148.

[26] T.M. Cocker, C.J. Fee, R.A. Evans, Preparation of magnetically susceptible polyacrylamide/magnetite beads for use in magnetically stabilized fluidized bed chromatography, Biotechnol. Bioeng. 53 (1997) 79-87.

[27] R.R. Dauer, E.H. Dunlop, High gradient magnetic separation of yeast, Biotechnol. Bioeng. 37 (1991) 1021-1028.

[28] A. Denizli, G. Özkan, M.Y. Arica, Preparation and characterization of magnetic polymethylmethacrylate microbeads carrying ethylene diamine for removal of $\mathrm{Cu}(\mathrm{II}), \mathrm{Pb}(\mathrm{II})$, and $\mathrm{Hg}(\mathrm{II})$ from aqueous solutions, J. Appl. Polym. Sci. 78 (2000) 81-89.

[29] P.A. Dresco, V.S. Zaitsev, R.J. Gambino, B. Chu, Preparation and properties of magnetite nanoparticles, Langmuir 15 (1999) 1945-1951.

[30] K. Furusawa, K. Nagashima, C. Anzai, Synthetic process to control the total size and component distribution of multilayer magnetic composite particles, Colloid Polym. Sci. 272 (1994) 1104-1110.

[31] V. Goetz, M. Remaud, D.J. Graves, A novel magnetic silica support for use in chromatographic and enzymatic bioprocessing, Biotechnol. Bioeng. 37 (1991) 614-626.

[32] M. Goto, T. Imamura, T. Hirose, Axial dispersion in liquid magnetically stabilized fluidized beds, J. Chromatogr. A 690 (1995) 1-8.

[33] D. Horák, J. Boháček, M. Šubrt, Magnetic poly (2-hydroxyethyl methacrylate-co-ethylene dimethacrylate) microspheres by dispersion polymerization, J. Polym. Sci.: Part A: Polym. Chem. 38 (2000) 1161-1171.

[34] H.P. Khng, D. Cunliffe, S. Davies, N.A. Turner, The synthesis of sub-micron magnetic particles and their use for preparative purification of proteins, Biotechnol. Bioeng. 60 (1998) 419-424.

[35] M.K. Li, J. Kessler, D.T. Bach, Magnetic separation device and methods for use in heterogeneous assays, US Patent 4,988,618 (1991).

[36] P.A. Liberti, Y.Z. Wang, W.X. Tang, B.P. Feeley, D.I. Gohel, Apparatus and methods for magnetic separation featuring external magnetic means, US Patent 5,466,574 (1995).

[37] T. Maekawa, M. Kuroshima, Microorganisms-immobilized magnetic carriers, a process for producing carriers, US Patent 6,043,068 (2000).

[38] R.S. Molday, J.B. Vancouver, Magnetic Iron-dextran Microspheres, US Patent 4,452,773 (1984).

[39] A.J. Richards, P.M. Lansdorp, Magnetic filter with ordered wire array, US Patent 5,439,586 (1995).

[40] M. Shinkai, M. Suzuki, M. Iijima, T. Kobayashi, Antibody-conjugated magnetoliposomes for targeting cancer cells and their application in hyperthermia, Biotechnol. Appl. Biochem. 21 (1994) 125-137.

[41] M. Stefan, Methods and materials for high gradient magnetic separation of biological materials, WO Patent 90/07380 (1990).

[42] M. Suzuki, M. Shinkai, M. Kamihira, T. Kobayashi, Preparation and characteristics of magnetite-labeled antibody with the use of poly (ethylene glycol) derivative, Biotechnol. Appl. Biochem. 21 (1995) 335-345.

[43] J. Ugelstad, T. Ellingsen, A. Berge, O.B. Helgee, Magnetic polymer particles and process for the preparation thereof, US Patent, 4,654,267 (1987).

[44] J. Ugelstad, P. Stenstad, L. Kilaas, Monodisperse magnetic polymer particles, Blood Purif. 11 (1993) 349-369.

[45] E. Pehlivan, T. Altun, The study of various parameters affecting the ion exchange of $\mathrm{Cu}^{2+}, \mathrm{Zn}^{2+}, \mathrm{Ni}^{2+}, \mathrm{Cd}^{2+}$, and $\mathrm{Pb}^{2+}$ from aqueous solution on Dowex 50W synthetic resin, J. Hazard. Mater. B 134 (2006) 146-159.

[46] B.X. Zhao, P. Wang, T. Zheng, C.Y. Chen, J. Shu, Preparation and adsorption performance of a cellulosic-adsorbent resin for copper(II), J. Appl. Polym. Sci. 99 (2006) 2951-2956.

[47] C. Sing, J. Yu, Copper adsorption and removal from water by living mycelium of white-rot fungus Phanerochaete Chrysosporium, Water Res. 32 (1998) 2746-2752.

[48] J.P. Chen, W.R. Chen, R.C. Hsu, Biosorption of copper from aqueous solutions by plant root tissues, J. Ferment. Bioeng. 81 (1996) 458-463. 